\title{
Arcadia y Edad de Oro en la configuración de la bucólica dieciochesca
}

FERNANDo R. DE LA FLOR

I. B. «Fray Luis de León». Salamanca

\section{El modelo áureo}

« $i$ Oh rey don Hernando y doña Ysabel en vos començaron los siglos dorados.»

JUAN DEL ENZINA

Traslación de las Bucólicas

En 1773, Dalmiro (Cadalso) interpreta, en unos versos hoy olvidados, la llegada de Batilo (Meléndez Valdés) a Salamanca al estilo de un viejo triunfo romano: el joven poeta, auxiliado por las musas y el espíritu de los Antiguos, bajo la advocación singular de Garcilaso, llega para instaurar un revival: el de los tiempos de Saturno (propiamente, el redeunt Saturnia regna, de la égloga IV virgiliana). Nueva Edad de Oro que hará retroceder el espíritu «pesado» del Estagirita y de Galeno:

Ya no verán, joh Tormes!

tus áridas orillas

los manes de Galeno, 
y del Estagirita.

Alza la anciana frente tanto tiempo oprimida, y esparce por el campo desde hoy jovial la vista. ¿No ves cómo se acercan con música festiva

a tus arenas sacras el gusto y la alegría?

En torno de ellas vuelan los juegos y las risas, cerca vienen las musas, del gran Phebo seguidas... ${ }^{1}$.

La utilización hiperbólica de este repertorio de signos clásicos habla elocuentemente del tipo de operación puesto en marcha, ya desde los prolegómenos «novatores» de la Ilustración; el objetivo declarado es la incardinación con la mejor tradición clásica española - la del primer Siglo de Oro-, de todo lo cual resulta un buen emblema la presencia inexcusable de Garcilaso («aparecieron los poetas bucólicos presididos por el dulcísimo Garcilaso...» ${ }^{2}$ ), en la que se sostiene con firmeza la propuesta de renovación que un Cadalso anticipa y que Meléndez Valdés, entre otros, llevará a cabo ${ }^{3}$.

En todos estos casos se trata de «reintroducir» (como ha escrito

1 Con motivo de haber encontrado en Salamanca un nuevo poeta de exquisito gusto, particularmente en las composiciones tiernas, en Obras de Don Joseph Cadalso, II (Madrid, 1803), 115.

2 «[...] cuyo candor, cuya ternura, cuya simplicidad, cuya rustiquez elegante dudo yo que tenga igual en ninguna lengua de las que hoy se hablan, porque no sé de cierto si en alguna de ellas hay tanta disposición como en la nuestra para tratar con elegancia el estilo pastoril y campestre» (J. P. Forner, Exequias de la lengua castellana-Madrid, s. f.-, 189).

3 El «príncipe de los poetas» lo es, sobre todo, de los poetas bucólicos, por lo que la reafirmación de su obra en el XVIII español supone la consagración de un género - la bucólica - y de una amplia temática — pastoril, rústica, mitológica, humanística, en sus términos más generales- que permea otros géneros. "Volverá - escribe el Conde de Torrepalma en 1750 - si la reverencia de nuestros mayores nos persuade que ha pasado, el Siglo de Oro de la poesía española y la rústica bucólica verá entre los humildes arbustos de sus felicísimas selvas nuevos Garcilasos, nuevos Boscanes... (Juicio lunático académico que de las obras de los Académicos de la Academia del Buen Gusto... Cit . por N. Marin, Poesía y poetas del Setecientos - Granada, 1971-, 175). Algunas de las paráfrasis que de las églogas de Garcilaso se realizan en el XVIII han sido puestas en evidencia por: J. Arce, «Diversidad temática y lingüística en la lírica dieciochesca»; J. Caso, J. Arce y J. A. Gaya Nuño, Los conceptos de Rococo, Neoclasicismo y Prerromanticismo en la poesía española del siglo XVIII, Cuadernos Cátedra Feijoo, 22 (1970), 37 y ss.; N. Marín, Poesía y..., y por mí mismo, a propósito de la obra de Diego González, en «La poesía pastoral de un poeta de la segunda escuela salmantina: Delio», Provincia de Salamanca, 1 (1982), 177-213. 
J. L. Abellán ${ }^{4}$ ) ideaciones que habían tenido su fuerza y su sentido en la España del siglo XVI.

Cadalso mismo, en una vinculación a la que no serán ajenos otros poetas de su tiempo, configura un paraíso histórico ambientado en las primeras décadas del siglo XVI ${ }^{5}$. El «renacer» del modelo renacentista -lo que también podríamos llamar un «neo-neoclasicismo»- alcanza por igual a todas las disciplinas humanísticas: artes ${ }^{6}$. y letras, en el interior de cuyo nuevo discurso escritores como Fray Luis de León van a ser objeto de una minuciosa labor de recuperación ${ }^{7}$. La ideología toda de la Ilustración aparece así sobredeterminada por los valores anteriormente adoptados por el clasicismo español. Lo neoclásico, entendido aquí como el estilo que pone en circulación la Ilustración, constituye un haz de «revivals»: se vinculará a lo griego ${ }^{8}$, a lo romano también, pero lo hace a través de la figura mediatizada del clasicismo del siglo XVI ${ }^{9}$.

La vieja constelación ideológica que había estructurado el llamado (y llamado antes que por nadie, por los propios intelectuales del Siglo de las Luces) Siglo de Oro retorna depurada: el erasmismo vuelve como espíritu «novator»y, más allá de ello, ilustrado ${ }^{10}$; el fisiocratismo estimula una recuperación del valor de la vida en el campo, que retoma, en libros como el de A. Muñoz, Morir viviendo en la aldea y vivir muriendo en la corte (Madrid, 1737), viejas argumentaciones que estaban en Guevara, en la Obra de Agricultura, de G. Alonso de Herrera y, más allá de ellos, en la de los tratadistas agrícolas romanos: Cato, Varro,

4 Cf. Del Barroco a la Ilustración, en Historia crítica del pensamiento español, III (Madrid, 1981), 379 y ss.

5 «La monarquía española - escribe- nunca fue más feliz por dentro, ni tan respetada por fuera, como en la época de la muerte de Fernando El Católico» (Cartas Marruecas, Carta XXX).

6. Cf. I. Henares Cuéllar, Teoría de las artes plásticas en España en la segunda mitad del siglo $X V I I I$ (Granada, 1977), 59 y ss.

7 La última aportación al tema de la influencia de Fray Luis de León en el siglo XVIII es la de A. Mestre, «El redescubrimiento de Fray Luis de León en el siglo XVIII», Bulletin Hispanique, 83 (1981), 5-64.

8 Lo griego modeliza muchas de las áreas culturales de la Ilustración española. No tenemos todavía un inventario completo de la influencia ejercida por la valoración de ese ideal. Aspectos parciales han sido tratados por C. Hernando, Helenismo e Ilustración (Madrid, 1975), y L. Gil, Panorama social del humanismo español (1500-1800), 429 y ss.

9 Quizá porque, como ha escrito Argan -Argan et alt., El pasado en el presente (Barcelona, 1974), 15-, el revival es un fenómeno repetitivo y se basa con frecuencia en otro revival.

10 Véase en A. Mestre, Despotismo e Ilustración en España (Barcelona, 1976), 56 y ss., el valor conferido a la supervivencia del espíritu erasmista. 
Columella, Palladius...; el neoplatonismo que configura la expresión lírica de las escuelas salmantina y sevillana del siglo XVI permea también el texto poético dieciochesco ${ }^{11}$.

En todos los vectores de la cultura dieciochesca se vive este reordenamiento de las líneas de conducción míticas, tradicionales y supersticiosas: $y$, mientras las últimas se desechan definitivamente, las segundas se depuran y las primeras se recuperan en una cierta medida que es la que tratamos de desentrañar.

Y en cuanto al género, que es uno de los centros donde se opera de manera más sistemática la «recuperación del Antiguo», en él, en la pastoril (si queremos seguir la nomenclatura de Sánchez Barbero o de Munárriz) o bucólica (operando con una sinécdoque) del dieciocho, encontramos de la manera más coherente esa apropiación del lenguaje de los clásicos (de todos los clásicos, que han ido labrando el género, la tradicionalidad de esta estructura): ese hablar en las palabras de otro, que de modo tan perfecto sirve a los propósitos de ocultación, de amparo en la autoridad del Antiguo, que caracteriza, según F. Venturi, la ideología ilustrada ${ }^{12}$.

La égloga, la bucólica, el idilio, la poesía pastoril en suma, funciona en el siglo XVIII como marco formal susceptible de ser «rellenado» de una materia diferente. Es en primer lugar, y en sí misma considerada, un modo de expresión «à clef»; un lenguaje cifrado cuyo convencionalismo funda una fratría, una sociedad, una academia. Los arcades arquitecturan parte de su vida íntima (cosa que revelan los epistolarios, las relaciones amorosas ${ }^{13}$, los movimientos dentro de la sociedad) en torno a este código, en líneas generales naturalista y pagano. El pastor se convierte en una figura transferencial del poeta y en su lenguaje toma cuerpo una reflexión autobiográfica en donde, categorializados y convencionalizados dentro del especial tipo de código comunicativo, residen los datos de la experiencia. Ya Lope, en su prólogo a la $A$ rcadia, escribía: «a vueltas de los ajenos pensamientos he llorado los míos».

11 Cf., como ejemplo particular de la ilación neoclasicismo/neoplatonismo, mi artículo «La filiación neoplatónica de un poema de Meléndez Valdés», Dieciocho, III, n. ${ }^{\circ} 1$ (1980), 51-62.

12 Véase una visión general del peso de la cultura clásica en el artículo de J. Arce «Cultura clásica y lírica neoclásica», 1616, 2 (1979), 13-24.

13 Escribe Dérozier a propósito: «Se difunde un culto por el erotismo que se diferencia algún tanto del buen gusto neoclásico, aunque se expresa a través de él y a través de un torbellino arcádico de pastores fingidos» (en «Visión cultural e ideológica», Centralismo, Ilustración y agonía del Antiguo Régimen (Barcelona, 1981), 400 . 
Este tipo de discurso, que organiza - como modélico- unas relaciones sociales de las cuales el texto ofrece una «traducción», acoge también una variedad de significaciones, de extralimitaciones de lo propiamente pastoril, de las cuales no puede decirse, aun cuando integran una temática absolutamente exótica, que sean novedosas, sino que estaban de alguna manera latentes en la propia tradición del género.

Encontramos así, cultivadas en mayor o menor medida, numerosas composiciones que configurarían una «pastoril fúnebre», que ya Bertana ${ }^{14}$ vinculó a las primeras manifestaciones prerrománticas ${ }^{15} . A r$ cadia lúgubre ésta que encierra una paradoja: la de la muerte, el alejamiento, la desgracia instalada en el territorio utópico; pero formulación que, más allá de la versión famosa que de ella daba Poussin $-E t$ in Arcadia Ego-, se encontraba en Virgilio, en aquella descripción de la muerte de Dafnis de la bucólica V. La alianza de muerte y melancolía en el seno del paisaje bucólico abre el paso a una lectura de muchos de estos poemas de finales del siglo XVIII como expresión de una suerte de «vanitas» arcádica; aspecto éste vinculado también a una dirección clásica que había conocido su primer rebrote en la lírica del XVI ${ }^{16}$.

Pero también, y junto a esto, se cultiva una pastoril áulica cuya tipificación integra una clara exaltación del Despotismo Ilustrado, evidente en textos como la égloga Con motivo de la exaltación al trono y proclamación de nuestro augusto soberano Carlos IV, de Fray Diego González, o la Noche pastoril y festiva, denominada Zagales de Carabias, que escribió Iglesias de la Casa «en loor del nacimiento de los dos serenísimos infantes gemelos Don Carlos y Don Felipe ${ }^{17}$. Bucólicas concebidas desde una posición ideológica de matiz regalista, en cuyo fondo resuenan las palabras de Juan del Enzina al frente del Cancionero:

No tengáis por mal, magnánimos príncipes, en dedicaros obra de pastores, pues no hay nombre más convenible al estado real, del cual nuestro Re-

14 Arcadia lúgubre e prerromántica, en In Arcadia (Napoli, 1909).

15 G. Carnero, recientemente - Sensibilidad, terror y medievalismo en la narrativa del siglo XVIII, en La cara oscura del Siglo de las Luces (Madrid, 1983), 95-123ha estudiado el gusto por lo macabro, tenebroso y lunar en el prerromanticismo español y europeo.

16 Véase, en este sentido, la «Introducción» de J. Lara Garrido a su edición de Las lágrimas de Angélica (Madrid, 1981), 23.

17 En la composición del anónimo Caballero de la Luenga Andanza, Egloga pastoril a la muerte de los Reyes Católicos (estudiada por N. Marín, Poesía y poetas..., 217 y ss.), la defensa monárquica se retrotrae a su origen: Edad de Oro ésta que se insinúa en el texto y constante punto de referencia para los cultivadores del género. 
dentor, que es el verdadero Rey de Reyes, se precia mucho, según parece en muchos lugares de la Sagrada Escritura. ${ }^{18}$

La identificación que se realiza entre la pastoril dieciochesca y la ideología cristiana tampoco resulta, a pesar de algunas extravagancias que en el siglo origina esta combinación, una formulación ajena a la tradicionalidad, estudiada hasta los umbrales del siglo XVIII por F. López Estrada ${ }^{19}$. La égloga puede servir en este punto para ofrecer una versión del Beatus ille luisiano o, tal vez, como soporte no-inocente de una reclamación jansenista sobre la independencia jurídica de las órdenes monásticas frente a Roma ${ }^{20}$. En cualquier caso, como ha visto Bayo $^{21}$, la religión no entra en la bucólica sin concesiones; su precio es una transformación, en el sentido de una paganización de lo específico cristiano.

Como otro registro más alcanzado por el género, se ha estudiado, a menudo desde perspectivas exclusivistas, la instrumentalización que de éste habrían realizado el fisiocratismo y la agronomía práctica, que se difunde y estimula desde las instituciones ilustradas. Fuera de que Azam, por ejemplo, haya demostrado recientemente lo problemático de una adscripción al fisiocratismo «sensu stricto» del pensamiento de Jovellanos, Meléndez, etc. ${ }^{22}$, queda la evidencia de la multitud de églogas, idilios, anacreónticas..., que no presentan rastro alguno susceptible de ser entendido bajo esa orientación. Por otra parte, la «poesía campestre» específica, al estilo de la que practica un Gregorio de Salas en el Observatorio rústico, se define en la elaboración de una noción de campo opuesta a la de ciudad y, en este sentido, esta dirección sólo presenta una cierta liminaridad con lo que propiamente sería el género pastoril; género cuya formulación abstrae (o suele hacerlo) la idea de la ciudad, ya que el tiempo ideal que diseña es un tiempo previo a la dialéctica ciudad/campo. La pastoril de este tiempo vehicula en consecuencia más ideología vinculada al humanismo agrícola, a la «pia rusticitas», a la «santa Agricultura» de los tratadistas renacentistas, que al espíritu del Informe librado por Jovellanos. La pastoril no cristalizaría,

18 De la ed. de Madrid 1928, fol. XXXI.

19 Cf. La línea de la tradición cristiana, en Los libros de pastores en la literatura española, I (Madrid, 1974), 152-206.

20 Véase en este sentido una composición como la de Diego González, El triunfo del Manzanares, estudiada en mi artículo «La poesía pastoral de un poeta de la segunda escuela salmantina», Provincia de Salamanca, 1 (1982), 201 y ss.

21 Virgilio y la pastoral española del Renacimiento (Madrid, 1970), 102.

22 Jovellanos est-il un physiocrate?, en Pensée hispanique et philosophie francaise (Toulouse, 1980). 
así, como un fisiocratismo sentimentalizado ${ }^{23}$, sino que sería el resultado de la revitalización - del «revival»-de una cultura clásica; revitalización, esto sí, que coincide con un deseo de capitalizar el medio rural por parte del pensamiento racionalista.

Quedaria, por último, en esta primera catalogación de las direcciones de lo arcádico dieciochesco, incluir lo que constituye su contrafigura, su parodización. Como en un negativo, lo pastoril se retoma desde su propia degradación manifiesta a lo largo del período barroco ${ }^{24}$. Lo que se rescata en esta cultura de lo utópico es el valor decaído de unas imágenes. Lo que se recicla es el prestigio perdido de unos topoi, de un lenguaje y de la ideología que lo subyace. Pero esta empresa es por definición efímera: cercado por un desgaste irreversible, el género sólo tendrá «modernidad» - es decir sentido en su tiempo- durante unos escasos años, en los que conoce su apoteosis. Años, décadas; la de los setenta y, acaso tambiẹn, la de los ochenta, que corren flanqueadas por la utilización paródica del lenguaje pastoril que llevaba a cabo, en los comienzos del siglo, un Torres y Villarroel, y en sus finales Ramón de la Cruz (La fingida Arcadia) ${ }^{25}$. Desde ese final, que reinaugura con extraordinaria acritud el texto satírico de Espronceda en El Artista (El pastor Clasiquino), han sido proyectados sobre el género toda clase de prejuicios ${ }^{26}$; prejuicios que no han valorado en este discurso, «el más antiguo de poesía» (Herrera), los materiales que transporta desde una clasicidad modélica.

La historia e identificación de estos materiales será, en buena medida, la historia del proceso que los lleva a su eclosión —entronizada

23 Como quiere J. I. Moreno en su artículo «Notas sobre la poesía del XVIII. A propósito de los Besos de amor», en Estudios sobre literatura y arte dedicados al pro-. fesor E. Orozco Díaz, II (Granada, 1979), 463-71, y como también en su momento propusieron, entre otros, Ciplijauskaité, Calvo Revilla y J. Casalduero; este último en su «Las nuevas ideas económicas sobre la agricultura en el siglo XVIII y el nuevo sentimiento de la naturaleza», La Torre, 61 (1968), 45-60.

$24 \mathrm{Y}$ de lo que se hace eco, entre otros muchos, Saavedra Fajardo, quien en su República literaria escribe: «Otro censor recibía los libros de poesía, en que había gran número de poemas pastorales, piscatorias, églogas y otras obras satíricas, y con mucha risa aplicaba los libros de materias amorosas para hacer cartones a las damas y capillos a las ruecas...»

25 Parodización que a menudo adopta el esquema dialéctico de una oposición ficción/realidad; como sucede en la Fábula $X V I$ de Samaniego: «Cierto joven leía / en versos excelentes / las dulces pastorelas / [...] / Dice: ¿Qué me sucede? / ¿Son éstos los pastores / discretos, inocentes / que pintan los poetas / tan delicadamente?»

26 Revisados algunos de ellos en mi reciente artículo «Convencionalismo y artificiosidad en la poesía bucólica de la segunda mitad del siglo XVIII», BOCES XVIII, 9 (1983), 55-67. 
como «moda»- en las décadas mencionadas. La potenciación que experimentan las dos ideaciones míticas - Edad de Oro y Arcadia- que constituyen el soporte imaginario de la pastoril y las razones y momentos de ese proceso, que ofrece un paralelo ideal al de la reforma política, económica y social de la Ilustración, ha de constituir, aunque de manera simplificada, parte de este análisis.

\section{El gabinete de los pastores}

«God made the country and man made the town.»

La trayectoria de la temática pastoril en -el siglo XVIII español es amplia y atraviesa vectorialmente todas las estéticas y todos los movimientos artísticos que en este siglo tienen vigencia. La recuperación lenta del prestigio de formas como las bucólicas, idilios, églogas..., no solamente en España sino en Europa entera, se inicia ya con el siglo, después de unas décadas que, entre 1680 y 1700 , corren caracterizadas por un absoluto abandono de las mismas; y después, sobre todo, de esa época de esplendor tardío de la pastoral, que ha estudiado recientemente J. Cascardi ${ }^{27}$. La transformación del género 0, más exactamente, el modo como los nuevos escritores encaran la antigua ficción pastoril, va definiéndose progresivamente hasta alcanzar su culminación en el último tercio del siglo XVIII.

En un principio, puede constatarse en la lírica española un aumento progresivo de la nómina de escritores que eligen el "pastoril estilo»; de este modo, la vista idílica de las pastorales comienza a ser uno de los temas más expresivos del momento literario que se vive. Estas primeras muestras setecentistas del género operan todavía con los elementos -el primero de ellos el propio lenguaje- heredados de la pastoril barroca, sin encontrar, en este primer momento, ese fondo galante que la hará tan peculiar dentro de la estética diecjiochesca, pero alojando ya un cierto gusto por el detalle, el uso de una mitología aminorada y parte de una imprecisa ternura y delicadeza que anuncia y constituye en buena medida el Rococó ${ }^{28}$. Por lo demás, églogas como la que Antonio José Porcel escribe hacia 1741 con el título de Adonis, se encuentran ya,

27 «The exit from Arcadia: Reevaluation of the pastoral in Virgil, Garcilaso and Góngora», Journal of Hispanic Philology, IV (1980), 119-41.

Sin entrar en la problemática de la propiedad de la adaptación del Rococó al terreno literario, hay que señalar que lo pastoril aparece como una de las manifestaciones más propias del estilo. Cf., por ejemplo, A. Schönberger y H. Sochner, Vida pastoral, en El Rococó y su época (Barcelona, 1971), 103-9. 
como Orozco ha reconocido, «más acorde con la temática del clasicismo en su nueva vuelta a la naturaleza y a los géneros grecolatinos y renacentistas» ${ }^{29}$.

El mismo aire de renovación y reinserción en el Antiguo se observa en otros poemas pastoriles hacia la misma época. Para algunos críticos del momento, resulta ya una evidencia el rompimiento con la grandilocuencia manifestada en la pastoril del Seiscientos, al tiempo que se hace también perceptible el deslizamiento hacia lo lírico de un género que había triunfado en las centurias anteriores en su forma prosificada. Escribe Benito Núñez, discípulo de Porcel, sobre las mismas églogas venatorias (que junto a las piscatorias forman una «desviación», apoyada con matizaciones por Luzán -Poética- y Sánchez Barbero -Principios de Poética-) del Adonis:

¿Cuándo hablaron tan dulces los pastores?
¿Cuándo las bellas ninfas así hablaron?
¿Cuándo en conceptos tales se explicaron
las finezas, los celos, los amores?
¿Cuándo de mitología los errores
con embelesos tales se escucharon? ${ }^{30}$.

A este "período alto» de la bucólica, que hemos acotado en torno a las décadas entre 1770 y 1790 , no se llega sin una reflexión previa, que sobre este tipo de poesía van a llevar a cabo los críticos de la Ilustración y, entre ellos, Luzán. Trata Luzán de un modo individualizado la égloga en su Poética. Incluida dentro del género de la poesía dramática, por su propio esquema compositivo basado en versos amebeos, en 1737, cuando Luzán publica su tratado, no está todavía definida la futura importancia de la poesía pastoril. Consciente, sin embargo, de que ya en ese momento hay escritores entregados a una escritura de temática bucólica, traza entre éstos (a los que llamará «imitadores») y los primitivos inauguradores del género una barrera separadora. Con ello, por vía indirecta, nos revela el crítico la existencia, en esas fechas, de un interés efectivo por la pastoril en nuestro país. Como síntoma, las escasas páginas de la Poética dedicadas a la égloga son elocuentes, pero lo son aún más por cuanto modelan unos presupuestos a los que el desarrollo futuro del género se va a atener minuciosamente. En cuanto al estilo de las églogas, que podemos hacer extensible a la pastoril en su generalidad, Luzán propone una facilidad, una naturalidad y una «suavidad», sancionadas luego por Forner cuando escribía: «Para mí el fundamento

29 Porcel y el barroquismo literario del siglo XVIII, en Cuadernos de la Cátedra Feijoo, 21 (1968), 51.

30 En L. A. de Cueto, Poetas líricos del siglo XVIII, I (Madrid, 1952), 137. 
del carácter bucólico no es otro que esa simplicidad en concebir las cosas y expresarlas del mismo modo que se conciben ${ }^{31}$.

En lo que se refiere a la oposición a un modelo de lírica barroca -oposición que es el bastidor donde se configura la poesía dieciochesca-, escribe el teórico sobre lo que sería preciso eliminar en la égloga nueva: «Los conceptos muy agudos, los colores retóricos muy subidos, $\mathrm{y}$ todo lo que manifieste mucho artificio» ${ }^{32}$.

Se revela, a través de lo esquemático de las propuestas de Luzán, de qué manera la égloga, y todo el género pastoril con ella, constituyen, por su naturaleza clásica, un territorio donde actuar decididamente contra el Barroco; un dique de moderación que levantar entre el Siglo de la Decadencia y el Siglo de las Luces.

Protagonistas, ambiente y lenguaje de la bucólica han de constituir, por lo mismo, lo imaginario de la cultura que los (re)genera; han de realizar en ellos esa sabia combinación de naturaleza y artificio que en todos los campos se presenta como lo más definitorio de la ideología que los alumbra ${ }^{33}$.

Asistimos aquí a la apertura de un doble proceso: por un lado, una parte de la vida social adopta el código pastoril para orientar sus conductas; por otro, los gustos y las modas permean el discurso literario. En el primer movimiento se cumple, a través de la decoración pastoril -que se realiza para las mascaradas, para las óperas bucólicas-, un proceso de fijación de la imaginería bucólica. Con la pintura ${ }^{34}$, que pone en pie una temática pastoril, nos encontramos ya en la prolongación cortesana y aun popular — social- de una configuración típicamente libresca. El mundo galante -y la parodización que del mismo se hace entre las clases populares - se apodera de la mitología pastoril y la utiliza como argumento decorativo, constituyendo en sus manos un «divertimento» no exento de melancolía.

La interpretación pictórica, nostálgica y mitológica de la Arcadia

31 Cotejo de las églogas ..., Ed. de F. Lázaro (Salamanca, 1951), 45.

32 La Poética (Zaragoza, 1737), 427.

33 En palabras de P. Francastel - La estética de las luces, en AAVV, Arte, arquitectura y estética en el siglo XVIII (Madrid, 1980), 49-: «El problema del siglo fue doble: descubrimiento de la naturaleza, pero también nostalgia de una cultura que intenta renovarse.» Véase, también, en este mismo sentido, E. L. Rivers, "The Pastoral Paradox of Natural Art», Modern Language Notes, 77 (1962), 130-44.

34 Para este tema es imprescindible la consulta del texto de los hermanos Gall La pintura galante (México, 1969). 
había renacido en el seno del Barroco con Poussin ${ }^{35}$; conforme avance el siglo XVIII, el tratamiento pictórico del tema deviene más teatral, y aloja en su espacio nuevos elementos, que son los manejados en la vida social circundante: tal la galantería y el carácter de disfraz que lo arcádico alcanza ${ }^{36}$.

El maridaje producido entre artes plásticas y temática pastoril no deja de tener en España algunas interpretaciones de interés, pero integrado como parte del discurso literario este acoplamiento alcanza una nueva dimensión. La propiedad de la temática arcádica en las pinturas se defiende, curiosamente, desde los poemas; lo pictórico mismo entra también como técnica de descripción y de ecfrasis dentro del texto, organizando, desde este punto de vista, el diseño de unos «cuadros» arcádicos, con todos los elementos del género. En otros casos, la pintura - su teoría - es susceptible de ser alegorizada bajo la cobertura pastoril; éste es el caso de un curioso libro que la imprenta Sancha dio a la luz el año 1794, y cuyo autor era Francisco Preciado, académico de la Escuela de San Fernando: Arcadia pictórica en sueño, alegoría o poema prosaico sobre la teoría y práctica de la pintura, escrita por Parrasio, pastor Arcade de Roma.

De la pintura, de la «decoración», en líneas generales de la literatura y el drama, algunos elementos pastoriles pasan con intensidad a convertirse en una suerte de moda dentro de la sociedad europea - y de su reflejo, la española- del siglo XVIII. El interés social que el mito arcádico aporta en este terreno reside en la confluencia dentro de él de dos mundos hasta entonces antagónicos: el destino minoritario, culto, artificioso que se le da a una sencillez original próxima a la naturaleza, expresa esta paradoja. Así, los signos que remiten a ese mundo arcádico, especie de grado cero del progreso, se revelan como susceptibles de ocultar la grandeza aristocrática o de enfatizar el temperamento artístico, ambos muy lejos de la felicidad primitiva y mítica. Asunción de una

35 Para el tema de la pintura en su relación con la pastoril española del siglo XVII, cf. J. Gállego, Visión y símbolos de la pintura española del Siglo de Oro (Madrid, 1975). Estudia Gállego la evolución del tipo iconográfico del pastor, desde las antiguas Anunciaciones hasta los finales del siglo XVII; época en que los personajes pastoriles «acusan ya su condición teatral». Otros temas relacionados con la iconografía pastoril en la época, en E. Orozco, Mística, plástica y Barroco (Madrid, 1977), 163 y ss.

36 Sobre la utilización del disfraz de pastor por los poetas de la Antigüedad, puede consultarse: A. Körte y P. Handel, La poesía helenística (Barcelona, 1975), 178 y ss. Juegos de corte y mascaradas pastoriles han sido analizados por F. López Estrada, Los libros de..., 478 y ss. Hay una fuente muy directa en la obra de Lope, Fiestas de Denia, relación de las celebraciones pastoriles con motivo del casamiento de Felipe II en Valencia, en 1599. 
convención por ćlases que, como en el caso de la esposa de Felipe de Orléans, gustan de decorar sus habitaciones privadas con las escenas de la novela pastoril griega Dafnis y $\mathrm{Cloe}^{37}$.

En estos ámbitos - también en el ficticio diseñado en el texto literario-, la mujer (lo femenino como categoría), luciendo el hábito de pastora, se convierte en el centro de una admiración intelectual, cortesana y galante, como la que revela el poema de Diego González dedicado a Maria Luisa de Parma:

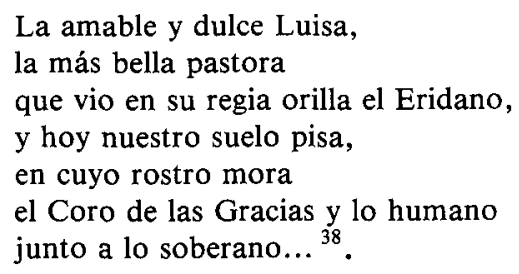

Fingida Arcadia, constelación de ninfas, vocabulario específico, semántica miniaturizada, mitología localista ésta que, instalándose en los salones -en los «gabinetes»-, ha sido modelizada desde el seno mismo del texto poético.

\title{
«Vita rústica»
}

\author{
[...] Vivió en la tierra, \\ pastor sencillo de ambición remoto, \\ al trato fácil y a la honesta risa, \\ y del pudor y la inocencia amigo. \\ $\mathrm{Ni}$ envidia conoció, ni orgullo insano. \\ Su corazón, como su lengua, puro. \\ Amaba la virtud, amó las selvas. \\ Diole su plectro y de olorosas flores \\ guirnalda le ciñó la que preside \\ al canto pastoril, divina Euterpe.
}

LEANDRo Fernández dE MoRatín

La poesía pastoril del siglo XVIII queda así configurada como uno de los artefactos culturales que reúnen en sus estructuras todas las ope-

37 La iconografía sobre los personajes de esta novela es muy abundante también en España. Goya mismo pinta, en 1771, un cuadro sobre este tema, del que se da noticia en Goya, 100 (1971), 204.

38 Llanto de Delio y profecía de Manzanares. Egloga, en Poesías del M. F. Diego González (Madrid, 1796), 12. 
raciones de recuperación de la clasicidad, bajo las condiciones de los nuevos tiempos. Arcadia y Edad de Oro funcionan en el interior mismo de este dispositivo a modo de mecanismos simbólicos, simbolizadores, alternativamente, de una vida íntima, de unas relaciones de círculos y academias, de una ideología, de una cultura (o de una manera de entender la cultura) y de un momento singular en la historia del país y en la de las formas del discurso literario.

A través de estas dos grandes unidades míticas - la Arcadia y la Edad de Oro- se formaliza gran parte de las experiencias poéticas que tienen lugar en el siglo. Este «modo bucólico», que las reúne y las vehicula, se extiende y pone bajo su concepción varios géneros y subgéneros, ocupando una franja significativa de la expresión literaria que va de lo épico a lo elegíaco; del epigrama a la estructura narrativodramática. Ambas configuraciones diseñan un sistema semiológico que no puede ser examinado aquí de una manera coherente y, para decirlo todo, estructural; más bien habrá de ser descrito - al menos mientras otros estudios no vengan a balizar este terreno- desde la perspectiva que sugiere la propia aparición de cadenas lineales de motivos y temas que pertenecen a uno u otro sistema. Pues la condición bajo la que estas dos concepciones míticas aparecen dentro de la bucólica dieciochesca es la de la propia ambigüedad, dispersión y condiciones de reutilización de un viejo material: su ordenación obedece a una técnica impresionista, donde los motivos se van superponiendo (como sucede en églogas como la I y la VI virgiliana), y en donde lo que se enlaza con contiguiidad, pero sin continuidad, es la descripción de los elementos de la naturaleza. Además, Arcadia y Edad de Oro son introducidas por una gran variabilidad de formas que cambian en el seno de cada uno de los poemas o, incluso, en sus distintas apariciones dentro de un mismo texto.

En definitiva, esta original Arcadia ilustrada que se revela en los textos se encuentra organizada en una infinidad potencial de cadenas asociativas que no pueden ser inventariadas de modo exhaustivo. El análisis, en consecuencia, se limita voluntariamente aquí a señalar la importancia de estas dos mitologías en el estadio dieciochesco del género y en ofrecer inordenadamente algunos de los motivos, temas, rasgos, loci communes y leit-motivs que las integran.

Más que de la bucólica, de la pastoril, se trata aquí de definir «lo bucólico», como organización simbólica de una gran parte de las experiencias poéticas que tienen lugar en el siglo XVIII español.

La poesía bucólica del siglo XVIII opera con los distintos motivos 
que aportan cinco grandes temas; todos ellos de clara raigambre clásica: aquellos que provienen de: (a) Paisaje bucólico: ya sean motivos vegetales, corrientes de agua, alusiones a las fuentes, a los arroyos o ríos, gruta de amor, abejas, cantos de cigarra, céfiros, rocas y monte; alusiones todas que contribuyen a la formación de un cuadro de naturaleza «animada», naturaleza conmovida - sacralizada, en cierta manera-, donde todos los elementos «hablan» al hombre, al pastor, al poeta. (b) Canto bucólico: el poema pastoril es expresión de un canto; en sentido restringido, es un metapoema: canto que habla de cómo fue el canto. Allí se despliega el aparato de su retórica: la excusatio, el motivo de la falsa modestia, la misma dedicatoria, la inscripción del canto en la roca o en la corteza, su reverberación en eco; también, la idea de su poder (mágico) en el nivel de los hechos naturales. (c) El canto evidencia el núcleo mismo de estas composiciones: revelar la índole particular del amor entre pastores. Así, en su apertura, o tal vez en la coda, expresando una suerte de suspensión conceptuosa, aparece la hermosura del amado, los motivos dolorosos de la ausencia, la infidelidad, la separación o ( $y$ alternativamente) los gozos del encuentro, de la caricia, del regalo, de la plática. El amor-pasión, la lascivia («amor caecus») o el amor-virtud (Cupido sin venda) aparecen antes convocados por los remedios del amor, también por los conjuros. Temática ésta vertida en una consideración melancólica, como la que revela el poema de Reinoso:

Tiempo, tiempo fugaz, ¿qué deliciosos

placeres nos llevaste! ¿Ay! ¿Te acuerdas? ${ }^{39}$.

Relato también de lo que fue y, en menor medida, expresión del deseo, arquitectura de lo imaginario. (d) La temporalidad concreta en que se instala la «historia pastoril» determina uno de sus temas estructuradores: el atardecer constituye siempre el marco cronológico del relato. Elección del crespúsculo con fuertes resonancias virgilianas («podría afirmarse que Virgilio descubrió la tarde ${ }^{40}$ ), y cuyos signos más inmediatos están constituidos por el regreso de los ganados, por las puestas de sol, por la aparición de las primeras estrellas vespertinas, en el entorno de una oscuridad creciente. Por último, y ésta es la unidad temática que aquí nos interesa, (e) la mitología bucólica: Arcadia y Edad de Oro. Mitología marcada por la constante alusión a los tiempos de Saturno, por las referencias explícitas a una paz, a una armonía, a

39 L. A. de Cueto, Poetas..., III, 228.

40 E. Panofsky, «Et in Arcadia Ego»: Poussin y la tradición elegíaca, en El significado en las artes visuales (Madrid, 1980), 327. 
una justicia entre los pastores. Territorio y tiempo donde no hay leyes, ni jerarquía, ni rastros de organización social. Tampoco diversidad de oficios, ni, en propiedad, trabajo. La tierra produce espontáneamente: hay miel, leche, aceite y néctar que circulan como regalo de los dioses. Estos últimos -y la poesía pastoril ostenta su propio Parnaso reducido ${ }^{41}$ - conviven armónicamente con los pastores: entienden de sus amores, reciben los sacrificos e intervienen sancionando con su autoridad la excelencia de una melodía o retirando súbitamente su afecto al hombre airado:

\author{
Rústico dios Pan \\ ruégote que asistas \\ a honrar mis cantares \\ con tu melodía. \\ Tú, inventor primero \\ de la flauta amiga ${ }^{42}$.
}

Es más, como resulta evidente, los dioses mismos aparecen aquí mezclados con la raza de los pastores (más allá de un oficio, lo pastoril es la única condición bajo la cual la humanidad existe en los aurea saecula), habitando su mundo, y convirtiéndose en imagen misma de lo que habían creado: condición pastoril que es también condición divina:

Pues Endimión, ¿quién fue? ¿No fue un vaquero?

Un vaquero también tú, Rhea, lloras

$Y$ tú, Jove iperdido no anduviste

por un muchacho, aunque zagal de bueyes? ${ }^{43}$

El cuadro idílico en su tradicionalidad nos presenta un espacio bajo la advocación de dos divinidades «mayores» (Venus-Apolo), susceptibles de ún desdoblamiento (Diana-Orfeo). El mundo arcádico, presidido por el principio del amor universal (amor-deseo, amornostalgia), está gobernado por las leyes del Arte y de la Compostura. Apolo impone una contención al juego de las pasiones y Orfeo dota de un contrapunto contemplativo a la naturaleza toda. En suma, desde Teócrito, un vasto territorio idílico se constituye en el ámbito en donde Venus-amor inspirada por Apolo-retórica recorre el gestuario del sentimiento humano.

41 «La mitología quedará, de una vez para siempre, unida a la literatura pastoril; y aun convertida mucho después en un ornamento poético, será precisa para obtener el ambiente necesario del género» (F. López Estrada, Los libros de..., 62).

42 J. Iglesias de la Casa, Al dios Pan, en L. A. de Cueto, Poetas..., I, 417.

43 El vaquero, Idilio de Teócrito, traducido por J. Meléndez Valdés, en L. A. de Cueto, Poetas..., III, 131. 
De estas cinco grandes unidades descritas ${ }^{44}$ es la última la que nos abre a la perspectiva bajo la cual, en definitiva, se configuran las restantes. La mitología, de obligada transparencia en la bucólica del siglo XVIII se encuentra asentada, sea cual fuere el tipo de mitemas que maneje, en la constancia de que el lugar de esos versos es la Arcadia (o alguna de sus prefiguraciones) y su tiempo (ideal, para oponerlo al tiempo concreto del atardecer en que se suele radicar la historia bucólica) el de una Edad de Oro, muchas veces poco definida en sus atributos.

Arcadia y Edad de Oro que, frente a otras ideaciones utópicas (Islas de los Bienaventurados descritas por Hesiodo, Píndaro o Platón; el Elíseo de Propercio; el Jardín de las Hespérides o el Paraíso terrenal del que se habla en Génesis y Números; la Insula deleitosa de los Amores de Clareo y Florisea; la Atlántida, el Dorado...), adquieren unos valores propios y aminorados, con respecto a los alcanzados en la misma clasicidad o en su primer «revival» español durante el siglo XVI. Originalidad que deviene ahora -en el siglo XVIII- de su desarrollo dentro de comunidades de intelectuales (arcades) que comparten los mismos sueños utópicos en el interior de una sociedad que abandona ya su raíz campesina y que, en consecuencia, comienza entonces a plantearse (aquí de modo imaginario) las condiciones de un reencuentro con ella.

Los mitos examinados denotan el universo bucólico, y lo hacen desde una paradoja: aquella que, junto a las marcas de un primitivismo natural, entrega también los signos de una civilización altamente refinada.

Esta disyunción se encuentra incardinada en los orígenes mismos del género que, en este caso, reproduce en su organización una problemática que le es ajena. En efecto, Arcadia y Edad de Oro -en su aparición en los textos de una extensa tradición- suministran de un modo paralelo una teoría de los inicios de la humanidad, junto a una especulación sobre los orígenes de la lírica. De este modo, un género - la poesía pastoril- vehicula un depósito mítico, donde residen los saberes sobre los orígenes de la humanidad y las condiciones del nacimiento del arte. Tales planteamientos constituyen una (re)creación cultural latina (Polibio, Historiae IV; Ovidio, Fasti II; Virgilio, Geórgicas I y II...), que vemos proyectarse sobre un género que preexistía a estas ideacio-

44 Véase otro modelo de análisis temático de la bucólica - concretamente las Bucólicas virgilianas - en F. López Estrada, «Los temas de la pastoral antigua», Anales de la Universidad Hispalense, 28 (1967), 132-82, y en Los libros de..., 76 y ss. 
nes, y que las seguirá albergando siglos después; género que había alcanzado su plena articulación en los Idilios de Teócrito.

La ilación entre una expresividad virtualmente utópica, como resulta ser la que transmite la poesía pastoril, y la creencia en la existencia de un «primitivismo blando» ${ }^{45}$, de una «edad de oro» habitada por «razas doradas», se imponia como una evidencia para la consideración de los teóricos del siglo XVIII. Por ejemplo, para Sánchez Barbero, que describe en clave mítica esa sociedad arcádica, productora genuina de la poesía pastoril: «tal fue la edad de oro y de la inocencia, pintada por los poetas antiguos, y tal en su principio la poesía pastoril, que podemos definir: la imitación de la vida campestre, representada con todos sus encantos» ${ }^{46}$. También para Luzán, implícitamente, cuando describe las costumbres de los pastores, su afición al canto, su hipotética «vida feliz», exenta de ambición y de fausto ${ }^{47}$. Cuestiones éstas que arrastraban una larga historia crítica, desde las primeras negaciones de esa Edad de Oro (y por consiguiente, de unos orígenes «realistas» para la poesía pastoril) realizadas por Lucrecio (De rerum Natura, 925 y ss.), Horacio (Sátiras, I, 3, 98 y ss.), Gratio (Cynegetica, 2-12)... Pasando por los planteamientos sobre el tema de Menéndez Pelayo ${ }^{48}$, hasta su elucidación final en artículos como el de E. Panofsky ${ }^{49}$, en el que se señala, por un lado, la tensión existente entre una pobre realidad geográfica - la Arcadia histórica ubicada en el Peloponeso- y la estructura mítica que la recubre, $y$, por otro, la desconexión existente entre la Arcadia, o la sociedad primitiva eminentemente rural que ella emblematiza, y la propia poesía bucólica.

El texto pastoril, desde esta moderna lectura, resulta ser una estructura de ficción que propaga una mitología (y también una ideología), una interpretación numinosa del pasado, un falseamiento de la historia; construcción de una utopía regresiva que la actitud revivalista de la Ilustración ensaya y desecha por última vez ${ }^{50}$. Todo apunta en ello

45 Para seguir la terminología propuesta por A. Lovejoy y G. Boas, A Documentary History of Primitivism and Related Ideas in Classical Antiquity (Baltimore, 1935).

46 Principios de Poética (Madrid, 1847), 176.

47 Poética, 427.

48 Que en sus Orígenes de la novela (II - Madrid, 1943-, 187 y ss.) da una interpretación del género bucólico como nacido en el seno de una sociedad refinada.

49 «Et in Arcadia ...» Véase una extensa bibliografía sobre la cuestión en las notas n. ${ }^{\circ} 40,41$ y 44 , de la p. 346.

50 Sin embargo, en un volumen como el editado por E. T. Lincoln -Pastoral and Romance. Modern Essays in Criticism (New Jersey, 1969)- se estudia la proyección que el género pastoril ha tenido hasta informar aspectos tan supuestamente alejados como la novela proletaria. 
hacia una visión irreal, utópica; objeto imaginario éste que vertebra la bucólica, y que Sánchez Barbero, una vez más, define:

El objeto de la égloga es el repaso pacífico de la vida campestre, exenta de ambición; es la abundancia y la alegría, la tranquilidad y el ocio, la franqueza y la libertad, la primavera y los valles, las contiendas poéticas, los amores sosegados y los placeres inocentes: es, en suma, la pintura de la Edad de Oro ${ }^{51}$.

De las tres formas de considerar la vida pastoril que repertorizaba Hugo Blair en su famosa obra Lecciones de Retórica, la última, «como jamás fue», es la opción mayoritariamente elegida por los poetas que cultivan la bucólica en el siglo XVIII. De esta última manera descriptiva decía Blair que era la más artificial porque mezclaba «la sencillez de las primeras edades con el gusto civilizado». Herrera mismo, en sus Anotaciones a las obras de Garcilaso, había realizado un esfuerzo por vincular las costumbres descritas en las Eglogas a una pretendidamente histórica Edad de Oro de la que serían un trasunto fiel ${ }^{52}$.

Los poetas del siglo XVIII patentizan todavía más las relaciones interiores existentes entre lo expresado por el discurso literario y la realidad histórica:

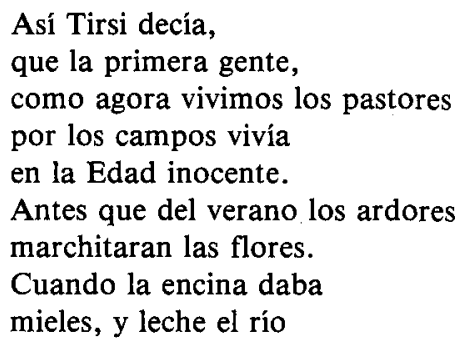

Ni se usaba el dinero, ni se labraba en dardos el acero ${ }^{53}$.

¡Oh tres y cuatro veces bienhadado

$\mathrm{El}$ primitivo siglo delicioso

Paciente vida, mansión preclara, libertad cara, tranquilo puerto, seguro, cierto.

51 Principios..., 177.

52 Vid. la ed. fac. (Madrid, 1973), 507.

53 J. Meléndez Valdés, Egloga I, en la ed. de la L. A. de Cueto, Poetas..., 177. 
¡Oh, ampárame! ¡Oh, recibeme en tus

brazos...! ${ }^{54}$.

Paraísos recordados y reconstruidos aquí, en las riberas renovadas del Henares, Tormes, Tajo, Betis undoso, a modo de palimpsestos - de pastiche, también de revival- donde resuenan los ecos de la tópica del Beatus ille ( «Canto el rústico bien, dulce reposo / vida feliz, de muchos envidiada. / Libre del necio mundo y sus cuidados... ${ }^{55}$ ) o del Locus amoenus ${ }^{56}$.

Esta Edad de Oro ubicada en la Arcadia se opone en todo a esa actual «guerra de Navarra», que irónicamente enfatizaba Espronceda en su sátira de lo bucólico: «Y estaba el pastor Clasiquino sin pensar ( $i$ oh quién pudiera hacer otro tanto!) en la guerra de Navarra». Y se opone también a la Edad de Hierro que se experimentaba en el campó español en el siglo XVIII: «Tal es -escribe Sánchez Barbero- la edad de nuestros pastores, edad de hierro y digna más bien de lástima que de ser cantada.»

La bucólica, que se acaba con el siglo, heredera con matices de aquella primera formulación revivalista de los mitos de la Arcadia y Edad de Oro que tuvo lugar en la villa medicea de Fiesole, reitera el tránsito de una Edad de Oro por venir a una Edad de Oro pasada. El motivo de la despedida de Arcadia es, aquí, paradigmático: melancolía, entonces, de una naturaleza adolescente, recreada y perdida una y otra vez en los poemas de Cadalso:

¡Adiós, Filis, adiós! No más amores

No más cantar por monte, selva o prado tu dulce nombre al eco enamorado.

Filósofo he de ser... ${ }^{57}$.

Conciencia del agotamiento de una mitología y de una edad que la fundamenta, la juventud:

\author{
Bosque hojoso, \\ floridos llanos, cristalino Tormes, \\ quedad por siempre adiós, dulces amigos.
}

54 J. Iglesias de la Casa, Egloga VII. En alabanza de la vida del campo, en L. A. de Cueto, Poetas.., I, 454.

55 J. M. Vaca de Guzmán, Columbano. Egloga, en L. A. de Cueto, Poetas..., I, 292.

56 «El locus amoenus -escribe Curtius, Literatura europea y Edad Media latina, I (México, 1976), 280 - es parte del escenario de la poesía bucólica.»

57 Sobre ser la poesía un estudio frívolo, y convenirme aplicarme a otros más serios, en L. A. de Cueto, Poetäs líricos.., I, 250. 
Adiós quedad, adiós; y tú indeleble conserva, árbol pomposo, la memoria que impresa dejo en tu robusto tronco, y sus letras en lágrimas bañadas: aqui Batilo fue feliz ${ }^{58}$.

Constatación también, por último, del recorrido seguido por una cultura carente ya de operatividad en las condiciones objetivas del nuevo mundo:

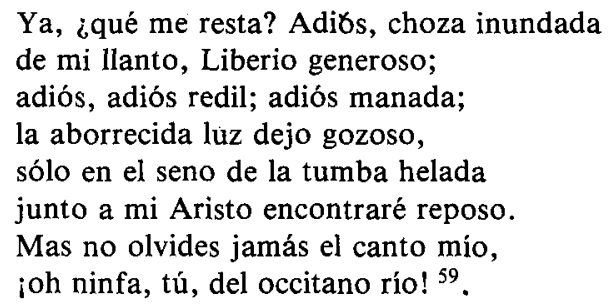

Aquí, en esta reaparición de la poesía bucólica en los decenios finales del siglo XVIII, una determinada dirección cultural se convierte en objeto de nostalgia; se da una «caída en la historia» ${ }^{60}$, que se deja sobornar por la belleza, nobleza y perfección de un ideal «griego» ${ }^{61}$. Utopía negativa, en resumidas cuentas, ésta que se presenta como una alienación de / en lo histórico, al tiempo que evasión para una élite. Ilusión cultural, sin embargo, tanto como naturalista, ya que recrea un espacio donde no existen la organización social ni el poder, y, en consecuencia, ofrece un territorio codificado por un repertorio de signos de lo natural.

Los mitos clasicistas que aquí hemos examinado estructuran un tipo de discurso literario que se prolonga y perpetúa a lo largo del siglo XVIII español; el comienzo de su superación puede fecharse en el mo-

58 J. Meléndez Valdés, Egloga V. El zagal del Tormes, en L. A. de Cueto, Poetas..., II, 182.

59 Alberto Lista, Egloga. Aristo, en L. A. de Cueto, Poetas..., III, 373.

6) Para emplear la terminología de Mircea Eliade, cuando se refiere a que toda cultura fija su ámbito imaginario con las marcas de un pasado histórico concreto. Cf. Imágenes y simbolos (Madrid, 1979), 186 y ss.

h R. Assunto escribe sobre Gessner: «Su poetización de lo campestre tiende a buscar la pureza de la antigüedado mediante la inversión temporal. Tendía también en poesía, teniendo a Teócrito como modelo, a hacer revivir la antigüedad - griega, singularmente- en tanto que arquetipo de toda perfección ético-estética, coincidencia de felicidad y virtud que constituye la base del Neoclasicismo» (El revival $v$ el problema del tiempo, en G. C. Argan et alt., El pasado en el presente (Barcelona, 1974), 30. 
mento en que son reconocidos como tales mitos, incapaces ya de ocupar un lugar en los modelos proyectivos del futuro: cuando se les identifica como valores realizables sólo a través de una adhesión incondicional, por encima de la historia y de la razón. 